\title{
Tricyclic antidepressant imipramine reduces the insulin secretory rate in islet cells of Wistar albino rats through a calcium antagonistic action
}

\author{
M.-H. Antoine ${ }^{1}$ D. Gall ${ }^{2}$ S. N. Schiffmann ${ }^{2} \cdot$ P. Lebrun ${ }^{1}$ \\ ${ }^{1}$ Laboratory of Pharmacology, Faculty of Medicine (CP 617), Université Libre de Bruxelles, Brussels, Belgium \\ ${ }^{2}$ Laboratory of Neurophysiology, Faculty of Medicine, Free University of Brussels, Brussels, Belgium
}

\begin{abstract}
Aims/hypothesis. Treatments with antidepressants have been associated with modifications in glucose homeostasis. The aim of this study was to assess the effect of imipramine, a tricyclic antidepressant, on insulinsecreting cells.

Methods. Insulin radioimmunoassay, radioisotopic, fluorimetric and patch-clamp methods were used to characterise the effects of imipramine on ionic and secretory events in pancreatic islet cells from Wistar albino rats.

Results. Imipramine induced a dose-dependent decrease in glucose-stimulated insulin output $\left(\mathrm{IC}_{50}=5.2 \mu \mathrm{mol} / \mathrm{l}\right)$. It also provoked a concentration-dependent reduction in ${ }^{45} \mathrm{Ca}$ outflow from islets perifused in the presence of $16.7 \mathrm{mmol} / \mathrm{l}$ glucose. Moreover, imipramine inhibited
\end{abstract}

the increase in ${ }^{45} \mathrm{Ca}$ outflow mediated by $\mathrm{K}^{+}$depolarisation. Patch-clamp recordings further revealed that imipramine provoked a marked and reversible decrease of the inward $\mathrm{Ca}^{2+}$ current. In single islet cells, imipramine counteracted the rise in $\left[\mathrm{Ca}^{2+}\right]_{\mathrm{i}}$ evoked by glucose or high $\mathrm{K}^{+}$concentrations.

Conclusions/interpretation. These data indicate that imipramine dose-dependently reduces the insulin secretory rate from rat pancreatic beta cells. Such an effect appears to be mediated by the inhibition of voltage-sensitive $\mathrm{Ca}^{2+}$ channels with subsequent reduction in $\mathrm{Ca}^{2+}$ entry. Thus, it is possible that some adverse effects of imipramine are related, at least in part, to its capacity to behave as a $\mathrm{Ca}^{2+}$ entry blocker.

Keywords $\mathrm{Ca}^{2+}{ }_{-}$channel $\cdot$ Imipramine Insulin release $\cdot$ Pancreatic beta cells

\section{Introduction}

Clinical and epidemiological studies have shown that depression is an underestimated disorder in Type 1 and Type 2 diabetic patients [1,2]. A higher prevalence has been reported in patients with diabetes mel-

Received: 24 October 2003 / Accepted: 26 January 2004

Published online: 16 April 2004

(C) Springer-Verlag 2004

P. Lebrun (

Laboratory of Pharmacology, Faculty of Medicine (CP 617),

Université Libre de Bruxelles, Lennik Street 808 ,

1070 Brussels, Belgium

E-mail: plebrun@ulb.ac.be

Tel.: +32-2-5556221, Fax: +32-2-5556356

Abbreviations: FOR, fractional outflow rate litus than in non-diabetic individuals [1, 2]. Moreover, depression may impair control of glycaemia and treatment compliance, as well as increasing the risk of vascular complications [1, 3].

Different classes of antidepressants commonly prescribed to depressed patients are also used in patients with depression and diabetes mellitus $[2,4,5,6]$. Successful drugs include tricyclic antidepressants (imipramine and imipramine-like compounds, which block the neuronal uptake of serotonin and norepinephrine) and the selective serotonin re-uptake inhibitors (typified by fluoxetine and sertraline). Other compounds such as tetracyclic antidepressants, norepinephrine reuptake inhibitors and monoamine oxidase inhibitors are also effective in treating the various forms of depressive disorders $[2,4,5,6]$.

Treatment with antidepressants has been reported to affect glucose homeostasis in diabetic and non-dia- 
betic individuals $[2,3,4,7,8]$. Tricyclic antidepressants but also selective serotonin re-uptake inhibitors have been shown to increase or decrease glycaemia with or without concomitant changes in plasma insulin $[2,3,4,7,9,10]$. Thus, although it is well recognised that antidepressants may affect blood glucose levels, the physiological mechanism(s) underlying these modifications in glucose homeostasis are not completely clear.

The aim of this study, therefore, was to examine, at the insulin-secreting cell level, the ionic and secretory effects of imipramine, a tricyclic antidepressant that has been used clinically for over three decades.

\section{Materials and methods}

Measurement of insulin secretion from incubated pancreatic islets. Experiments were performed with pancreatic islets isolated by the collagenase method from fed female Wistar albino rats (180-220 g, Charles River Laboratories, Brussels, Belgium) $[11,12]$. Laboratory animal care was approved by the Ethics Committee of the Université Libre de Bruxelles (Free University of Brussels).

Groups of ten islets, each derived from the same batch of islets, were pre-incubated for $30 \mathrm{~min}$ at $37{ }^{\circ} \mathrm{C}$ in $1 \mathrm{ml}$ of a physiological salt medium (in mmol/l: $\mathrm{NaCl} 115, \mathrm{KCl} 5, \mathrm{CaCl}_{2}$ 2.56, $\left.\mathrm{MgCl}_{2} 1, \mathrm{NaHCO}_{3} 24\right)$ supplemented with $2.8 \mathrm{mmol} / \mathrm{l}$ glucose, $0.5 \%(\mathrm{w} / \mathrm{v})$ dialysed albumin (Fraction V; SigmaAldrich, Bornem, Belgium) and equilibrated against a mixture of $\mathrm{O}_{2}(95 \%)$ and $\mathrm{CO}_{2}(5 \%)$. The islets were then incubated for $90 \mathrm{~min}$ at $37{ }^{\circ} \mathrm{C}$ in $1 \mathrm{ml}$ of the same medium containing $16.7 \mathrm{mmol} / \mathrm{l}$ glucose and, in addition, increasing concentrations of imipramine. Experiments were repeated on different islets populations. Insulin release was expressed as a percentage of the value recorded in control experiments $(100 \%)$, i.e. in the absence of drug and presence of $16.7 \mathrm{mmol} / \mathrm{l}$ glucose. The release of insulin was measured radioimmunologically using rat insulin as a standard [13].

Measurements of ${ }^{45} \mathrm{Ca}$ outflow and insulin release from perifused pancreatic islets. The medium used for incubating, washing and perifusing the islets consisted of a bicarbonatebuffered solution having the following composition (in mmol/l): $\mathrm{NaCl} 115, \mathrm{KCl} 5, \mathrm{CaCl}_{2} 2.56, \mathrm{MgCl}_{2} 1, \mathrm{NaHCO}_{3} 24$. The medium was supplemented with $0.5 \%(\mathrm{w} / \mathrm{v})$ dialysed albumin (Fraction $\mathrm{V}$ ) and equilibrated against a mixture of $\mathrm{O}_{2}$ $(95 \%)$ and $\mathrm{CO}_{2}(5 \%)$.

The methods used to measure ${ }^{45} \mathrm{Ca}$ outflow and insulin release from perifused islets have been described previously $[14,15]$. Briefly, groups of 100 islets were incubated for $60 \mathrm{~min}$ in a medium containing $16.7 \mathrm{mmol} / 1$ glucose and ${ }^{45} \mathrm{Ca}$ ion $\left(0.02-0.04 \mathrm{mmol} / \mathrm{l} ; 3.70 \times 10^{6} \mathrm{~Bq} / \mathrm{ml}\right)$. After incubation, the islets were washed four times with a non-radioactive medium and then placed in a perifusion chamber. The perifusate was delivered at a constant rate $(1.0 \mathrm{ml} / \mathrm{min})$. From the $31 \mathrm{st}$ to the 90th minute of perifusion, the effluent was continuously collected over successive periods of $1 \mathrm{~min}$ each. An aliquot of the effluent $(0.6 \mathrm{ml})$ was used for scintillation counting while the remainder was stored at $-20{ }^{\circ} \mathrm{C}$ for insulin radioimmunoassay [13]. At the end of perifusion, the radioactive content of the islets was also determined. The outflow of ${ }^{45} \mathrm{Ca}(\mathrm{cpm})$ was expressed as a fractional outflow rate (FOR; percent of instantaneous islet content per minute).
Electrophysiological measurements. Electrophysiological studies were carried out on isolated rat pancreatic islet cells. Pancreatic islets were disrupted in a $\mathrm{Ca}^{2+}$-deprived medium and then centrifuged through an albumin solution to remove debris and dead cells $[11,15]$. Insulin-secreting cells were selected on the basis of their larger size [16].

Whole-cell $\mathrm{Ca}^{2+}$ currents were recorded using the perforated patch whole-cell configuration [17] of the patch-clamp technique [18]. The standard extracellular solution was composed of (in mmol/l): $\mathrm{NaCl} \mathrm{118,} \mathrm{tetraethylammonium} \mathrm{chloride} \mathrm{20,}$ $\mathrm{KCl} 5.6, \mathrm{CaCl}_{2}$ 2.6, $\mathrm{MgCl}_{2}$ 1.2, glucose 5 and HEPES 5 (pH adjusted to 7.40 with $\mathrm{NaOH}$ ). The effect of imipramine was investigated on single beta cells by switching from the standard extracellular solution to the same solution supplemented with $100 \mu \mathrm{mol} / \mathrm{l}$ imipramine. In some experiments, $10 \mu \mathrm{mol} / \mathrm{l}$ tetrodotoxin was added to the extracellular solution to block a potential remaining $\mathrm{Na}^{+}$current. The pipette was filled with (in mmol/l): $\mathrm{Cs}_{2} \mathrm{SO}_{4} 76, \mathrm{KCl} 10, \mathrm{NaCl} 10, \mathrm{MgCl}_{2} 1$ and HEPES 5 ( $\mathrm{pH}$ adjusted to 7.35 with $\mathrm{CsOH})$. Amphotericin B $(0.24 \mu \mathrm{g} / \mathrm{ml})$ was included in the pipette solution in order to establish electrical contact with the cell interior. Ionic currents were recorded using an EPC-8 amplifier (HEKA, Lambrecht/Pfalz, Germany) and stored on a computer. The pulse software (HEKA) and an ITC-16 AD/DA converter (Instrutech, New York, USA) were used to acquire the data. The current signals were digitised at $2 \mathrm{kHz}$. Prior to digitising, the signals were filtered at $500 \mathrm{~Hz}$ using an 8-pole low-pass Bessel filter (Frequency Devices, Haverhill, Mass., USA). All experiments were carried out at room temperature. The voltage clamp protocol consisted of 450-ms depolarisation pulses starting from a holding potential of $-70 \mathrm{mV}$ and ranging from $-40 \mathrm{mV}$ to $+30 \mathrm{mV}$.

Measurements of fura-2 fluorescence from single rat pancreatic islet cells. The cells were placed on glass coverslips and maintained in tissue culture for $72 \mathrm{~h}$ before use. Islet cells were cultured in RPMI 1640 culture medium (Invitrogen, Merelbeke, Belgium) supplemented with $10 \%$ (v/v) newborn calf serum and containing glutamine $(2.3 \mathrm{mmol} / \mathrm{l})$, penicillin $\mathrm{G}(100 \mathrm{U} / \mathrm{ml})$ and streptomycin $(100 \mu \mathrm{g} / \mathrm{ml})$. The cells were then incubated with fura-2 AM (final concentration: $2 \mu \mathrm{mol} / \mathrm{l}$ ) for $1 \mathrm{~h}$ and, after washing, the coverslips with the cells were mounted as the bottom of an open chamber $(1 \mathrm{ml})$ placed on the stage of the microscope. The medium used to perifuse the cells contained (in mmol/l): $\mathrm{NaCl} 115, \mathrm{KCl} 5, \mathrm{CaCl}_{2} 2.56, \mathrm{MgCl}_{2} 1, \mathrm{NaHCO}_{3} 24$, glucose 2.8. It was gassed with $\mathrm{O}_{2}(95 \%)$ and $\mathrm{CO}_{2}(5 \%)$. Fura-2 fluorescence of single loaded cells (selected on the basis of their larger size) was measured by dual-excitation microfluorimetry with a Spex photometric system (Optilas, Alphen aan den Rijn, The Netherlands). The excitation wavelengths $(340 \mathrm{~nm}$ and $380 \mathrm{~nm})$ were alternated at a frequency of $1 \mathrm{~Hz}$, the length of time for data collection at each wavelength being 0.05 seconds. The emission wavelength was set at $510 \mathrm{~nm}$. We calculated $\left[\mathrm{Ca}^{2+}\right]_{\mathrm{i}}$ as described previously $[11,15]$. Individual experiments were repeated at least four times, on different cell populations.

Drugs. In some experiments, extracellular $\mathrm{Ca}^{2+}$ was eliminated by omitting $\mathrm{CaCl}_{2}$ from the physiological medium and adding $0.5 \mathrm{mmol} / \mathrm{l}$ EGTA (Sigma-Aldrich). Depending on the experiment, the media were enriched with glucose (Merck, Darmstadt, Germany), imipramine (Sigma-Aldrich) or tetrodotoxin (Acros Organics, Kortrijk, Belgium). When high concentrations of extracellular $\mathrm{K}^{+}$were used, the concentration of $\mathrm{NaCl}$ was lowered to keep osmolarity constant.

Calculations. Results are expressed as means \pm SEM. The increase in ${ }^{45} \mathrm{Ca}$ outflow was estimated in each individual experi- 
ment from the integrated outflow of ${ }^{45} \mathrm{Ca}$ observed during stimulation (45th-68th $\mathrm{min}$ ) after correction for basal value (40th-44th min). Peak ${ }^{45} \mathrm{Ca}$ outflow was estimated from the difference in ${ }^{45} \mathrm{Ca}$ outflow between the highest value recorded during stimulation and the mean basal value (40th-44th min) within the same experiment. The inhibitory effect of imipramine on ${ }^{45} \mathrm{Ca}$ outflow and insulin release from islets perifused in the presence of $16.7 \mathrm{mmol} / \mathrm{l}$ glucose was taken as the difference between the mean value for ${ }^{45} \mathrm{Ca}$ outflow or insulin output recorded in each individual experiment between the 40th and 44th and the 60th and 68th min of perifusion. The statistical significance of differences between mean data was assessed by Student's $t$ test or by analysis of variance followed by a Scheffe test procedure. A $p$ value of less than 0.05 was considered significant.

\section{Results}

Effects of imipramine and fluoxetine on insulin release from incubated rat pancreatic islets. In rat pancreatic islets exposed to $5.6 \mathrm{mmol} / \mathrm{l}$ glucose, the addition of $100 \mu \mathrm{mol} / \mathrm{l}$ of imipramine did not affect insulin output (data not shown).

By contrast, imipramine inhibited insulin release from pancreatic islets incubated in the presence of an intermediate insulinotropic glucose concentration. Thus, in the simultaneous presence of $8.3 \mathrm{mmol} / \mathrm{l}$ glucose and $100 \mu \mathrm{mol} / \mathrm{l}$ imipramine in the incubation medium, the insulin output averaged $55.6 \pm 5.4 \%$ of the control experiments $(p<0.05)$.

Moreover, the addition of increasing concentrations of imipramine to pancreatic islets incubated in the presence of $16.7 \mathrm{mmol} / \mathrm{l}$ glucose provoked a concentration-dependent decrease in insulin release (Fig. 1). After the addition of $1 \mu \mathrm{mol} / \mathrm{l}, 10 \mu \mathrm{mol} / \mathrm{l}$ and $100 \mu \mathrm{mol} / 1$ imipramine, the residual insulin release averaged $90.6 \pm 5.8 \% \quad(p>0.05), 38.3 \pm 2.6 \% \quad(p<0.05)$ and $9.9 \pm 0.7 \%(p<0.05)$ of the control value. The $\mathrm{IC}_{50}$ value (drug concentration evoking a 50\% reduction of the secretory response to $16.7 \mathrm{mmol} / \mathrm{l}$ glucose) amounted to $5.2 \mu \mathrm{mol} / \mathrm{l}$.

Effects of imipramine on ${ }^{45} \mathrm{Ca}$ outflow and insulin release from perifused rat pancreatic islets. In the presence of $5.6 \mathrm{mmol} / \mathrm{l}$ glucose throughout, and regardless of whether the medium contained or was deprived of extracellular $\mathrm{Ca}^{2+}$, the addition of $10 \mu \mathrm{mol} / 1$ imipramine did not affect the rate of ${ }^{45} \mathrm{Ca}$ outflow from prelabelled and perifused rat pancreatic islets (data not shown).

By contrast, when the physiological medium contained $16.7 \mathrm{mmol} / 1 \mathrm{instead}$ of $5.6 \mathrm{mmol} / \mathrm{l}$ glucose, exposure to 10 or $100 \mu \mathrm{mol} / \mathrm{l}$ imipramine provoked an immediate and reversible inhibition of ${ }^{45} \mathrm{Ca}$ outflow from islets perifused in the presence of extracellular $\mathrm{Ca}^{2+}$ (Fig. 2a, b). The imipramine-induced reduction in the ${ }^{45} \mathrm{Ca}$ FOR was more rapid and more pronounced at the higher concentration. The paired difference in the ${ }^{45} \mathrm{Ca}$ FOR before (40-44 $\mathrm{min}$ ) and during

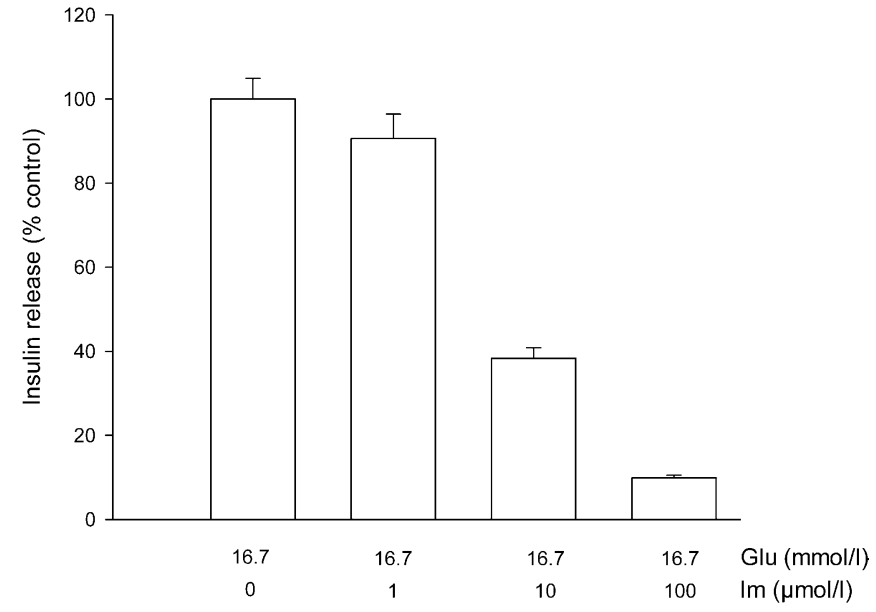

Fig. 1. Effect of increasing concentrations of imipramine (Im) on insulin release from pancreatic islets incubated in the presence of $16.7 \mathrm{mmol} / \mathrm{l}$ glucose (Glu). Insulin release (means \pm SEM) is expressed as a percent of the value for control experiments $(100 \%$, no added drug, presence of $16.7 \mathrm{mmol} / \mathrm{l}$ glucose). The upright lines at the top of the bars correspond to the SEM. Number of samples: $0 \mu \mathrm{mol} / 1 \mathrm{Im}: 31 ; 1 \mu \mathrm{mol} / 1 \mathrm{Im}: 23$; $10 \mu \mathrm{mol} / 1 \mathrm{Im}: 23$; $100 \mu \mathrm{mol} / 1 \mathrm{Im}: 25$

(60-68 min) exposure to $10 \mu \mathrm{mol} / \mathrm{l}$ and $100 \mu \mathrm{mol} / \mathrm{l}$ imipramine averaged $0.72 \pm 0.01 \% / \mathrm{min}$ and $1.02 \pm$ $0.07 \% / \mathrm{min}$ respectively $(p<0.05)$.

On removal of the drug from the perifusing medium, ${ }^{45} \mathrm{Ca}$ outflow increased. This increase was delayed after removal of the higher drug concentration (compare Fig. 2a and b).

The decreases in the ${ }^{45} \mathrm{Ca}$ FOR induced by the addition of $10 \mu \mathrm{mol} / \mathrm{l}$ and $100 \mu \mathrm{mol} / \mathrm{l}$ imipramine were accompanied by concentration-dependent reductions in insulin output (Fig. 2c, d). In the presence of $10 \mu \mathrm{mol} / \mathrm{l}$ and $100 \mu \mathrm{mol} / \mathrm{l}$ imipramine $(60-68 \mathrm{~min})$, the release of insulin represented $31.10 \pm 1.08 \%$ and $18.62 \pm 1.75 \%$ of the secretory rate recorded before administration of the drug $(40-44 \mathrm{~min})(p<0.05)$. The withdrawal of $10 \mu \mathrm{mol} / \mathrm{l}$ imipramine was followed by a rapid increase whilst the withdrawal of $100 \mu \mathrm{mol} / 1$ imipramine was followed by a weak increase in insulin output (Fig. 2c, d).

To further investigate the effects of imipramine on radioisotopic fluxes, the experiments were repeated in the absence of extracellular $\mathrm{Ca}^{2+}$ (Fig. 2a, b). In islets exposed throughout to $16.7 \mathrm{mmol} / 1$ glucose and $\mathrm{Ca}^{2+}$ depleted media, the rate of ${ }^{45} \mathrm{Ca}$ outflow before drug administration (40-44 min) was lower $(p<0.05)$. Under the latter conditions, $10 \mu \mathrm{mol} / \mathrm{l}$ imipramine did not affect ${ }^{45} \mathrm{Ca}$ outflow (Fig. 2a). The addition of $100 \mu \mathrm{mol} / \mathrm{l}$ imipramine, however, provoked a modest but sustained and reversible rise in the ${ }^{45} \mathrm{Ca}$ FOR (Fig. 2b).

Effects of imipramine on $\mathrm{KCl}$-induced changes in ${ }^{45} \mathrm{Ca}$ outflow from perifused rat pancreatic islets. In the presence of $2.8 \mathrm{mmol} / \mathrm{l}$ glucose and extracellular $\mathrm{Ca}^{2+}$, 

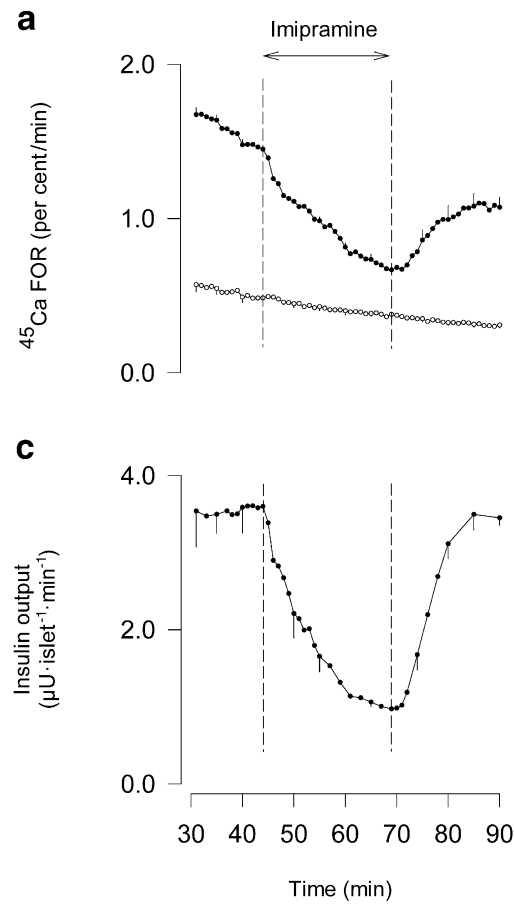

Fig. 2. Effect of $10 \mu \mathrm{mol} / \mathrm{l}(\mathbf{a}, \mathbf{c})$ and $100 \mu \mathrm{mol} / \mathrm{l}$ (b, d) imipramine on ${ }^{45} \mathrm{Ca}$ outflow $(\mathbf{a}, \mathbf{b})$ and insulin release $(\mathbf{c}, \mathbf{d})$ from pancreatic islets perifused throughout in the presence of $16.7 \mathrm{mmol} / \mathrm{l}$ glucose. Basal media contained extracellular $\mathrm{Ca}^{2+}$

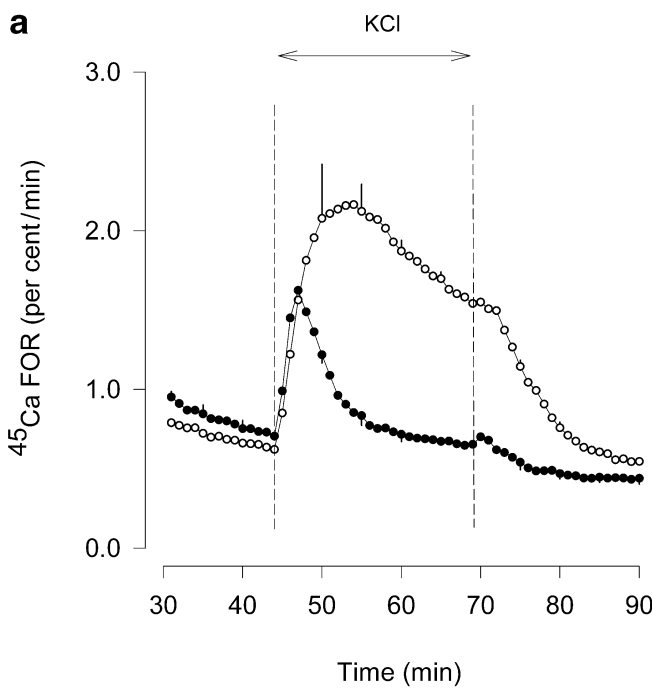

Fig. 3. Effect of a rise in the extracellular $\mathrm{K}^{+}$concentration from 5 to $50 \mathrm{mmol} / \mathrm{l}$ on ${ }^{45} \mathrm{Ca}$ outflow from pancreatic islets perifused throughout in the absence $(\bigcirc)(\mathbf{a}, \mathbf{b})$ and the presence $(\mathbf{O})$ of $10 \mu \mathrm{mol} / \mathrm{l}(\mathbf{a})$ or $100 \mu \mathrm{mol} / \mathrm{l}$ (b) imipramine. Basal media contained $2.8 \mathrm{mmol} / \mathrm{l}$ glucose and extracellular $\mathrm{Ca}^{2+}$. Mean values ( \pm SEM) refer to four to six individual experiments. FOR, fractional outflow rate

a sudden rise in the extracellular concentration of $\mathrm{K}^{+}$ provoked an immediate and pronounced increase in ${ }^{45} \mathrm{Ca}$ outflow from prelabelled and perifused rat pancreatic islets (Fig. 3a, b).
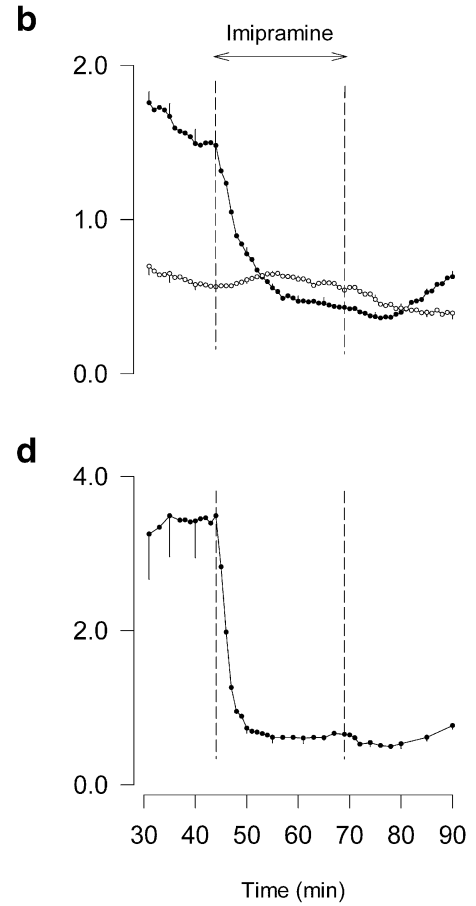

) or were deprived of $\mathrm{Ca}^{2+}$ and enriched with EGTA $(\bigcirc)$. Mean values $( \pm$ SEM) refer to four or five individual experiments. FOR, fractional outflow rate

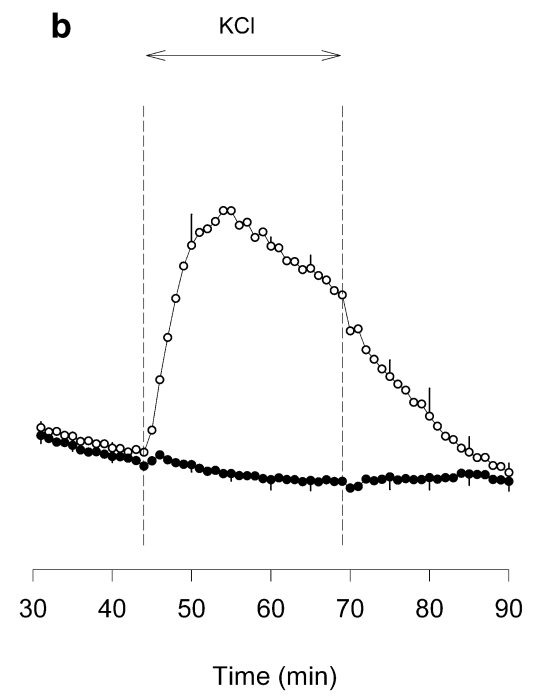

When the same experiment was repeated with either $10 \mu \mathrm{mol} / \mathrm{l}$ (Fig. 3a) or $100 \mu \mathrm{mol} / \mathrm{l}$ (Fig. 3b) imipramine in the medium, the basal rate of ${ }^{45} \mathrm{Ca}$ outflow was unaffected $(p>0.05)$. However, the presence of imipramine in the physiological medium markedly reduced the cationic response to $\mathrm{K}^{+}$. The increase in ${ }^{45} \mathrm{Ca}$ outflow evoked by $50 \mathrm{mmol} / \mathrm{l} \mathrm{K}^{+}$averaged $1.18 \pm 0.14 \% / \mathrm{min}$ in the absence and $0.18 \pm 0.06 \% / \mathrm{min}$ in the presence of $10 \mu \mathrm{mol} / \mathrm{l}$ imipramine $(p<0.05)$. The peak ${ }^{45} \mathrm{Ca}$ outflow observed during exposure to $\mathrm{K}^{+}$ averaged $1.66 \pm 0.20 \% / \mathrm{min}$ and $0.92 \pm 0.08 \% / \mathrm{min}$ in the absence and presence of $10 \mu \mathrm{mol} / \mathrm{l}$ imipramine respectively $(p<0.05)$. 

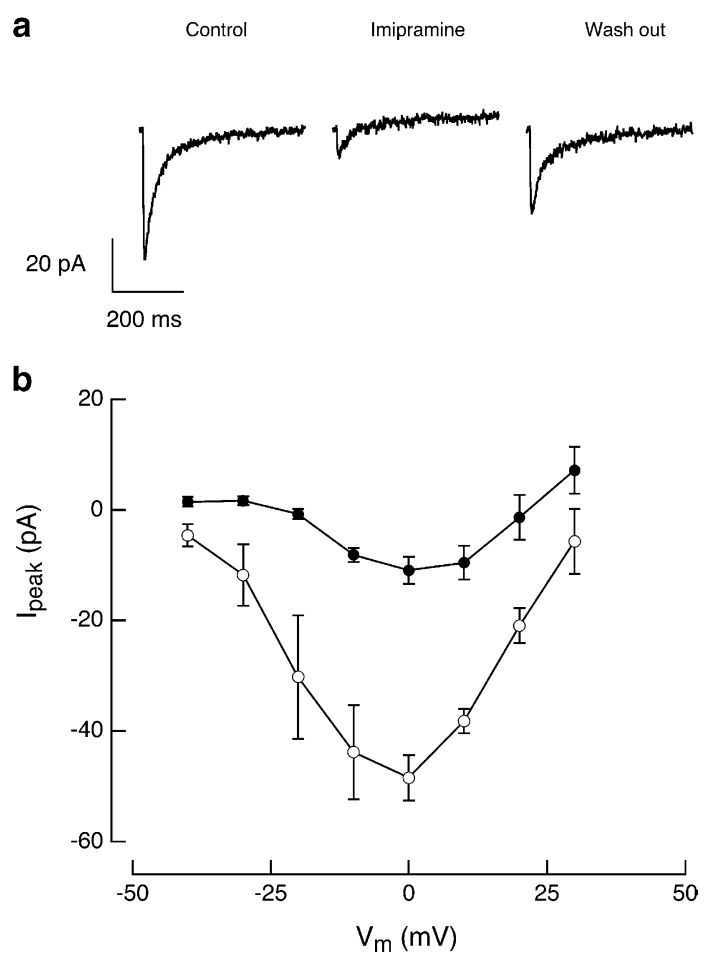

Fig. 4. Effect of $100 \mu \mathrm{mol} / \mathrm{l}$ imipramine on the voltage dependence of the inward $\mathrm{Ca}^{2+}$ current. a. Typical recordings of whole-cell $\mathrm{Ca}^{2+}$ currents observed during a 450-ms depolarising pulse from a holding potential of $-70 \mathrm{mV}$ to $0 \mathrm{mV}$ on a single islet cell. b. Corresponding I-V relationships obtained with voltage clamp protocol consisting of 450-ms depolarisation pulses starting from a holding potential of $-70 \mathrm{mV}$ and ranging from $-40 \mathrm{mV}$ to $+30 \mathrm{mV}$ in the absence (control condition, $\bigcirc$ ) and presence $(9)$ of $100 \mu \mathrm{mol} / 1$ imipramine. Mean values $( \pm$ SEM) refer to five individual experiments

In islets exposed throughout to $100 \mu \mathrm{mol} / \mathrm{l}$ imipramine, the stimulatory effect of high extracellular $\mathrm{K}^{+}$ was completely abolished (Fig. 3b).

Effect of imipramine on the inward $\mathrm{Ca}^{2+}$ current in single rat pancreatic islet cells. This effect was investigated by means of the perforated patch configuration of the patch-clamp technique. We investigated the dependence of the $\mathrm{Ca}^{2+}$ current on the voltage using $450 \mathrm{~ms}$ depolarisation pulses. Each depolarising pulse was separated from the following by 20 seconds to allow return to the basal calcium level [19]. Depolarisations from a holding potential of $-70 \mathrm{mV}$ to voltages between $-40 \mathrm{mV}$ and $+30 \mathrm{mV}$ evoked an inward current that reached a maximum amplitude around $0 \mathrm{mV}$, with gating properties consistent with the slowly deactivating $\mathrm{Ca}^{2+}$ current (L-type $\mathrm{Ca}^{2+}$ channels) described in rat beta cells [20]. This inward current was insensitive to the application of $10 \mu \mathrm{mol} / 1$ tetrodotoxin (data not shown), thereby confirming that it was not due to the activation of $\mathrm{Na}^{+}$channels.

Figure $4 \mathrm{a}$ illustrates the effect of $100 \mu \mathrm{mol} / \mathrm{l} \mathrm{imi}-$ pramine on the inward current evoked by depolarisa-
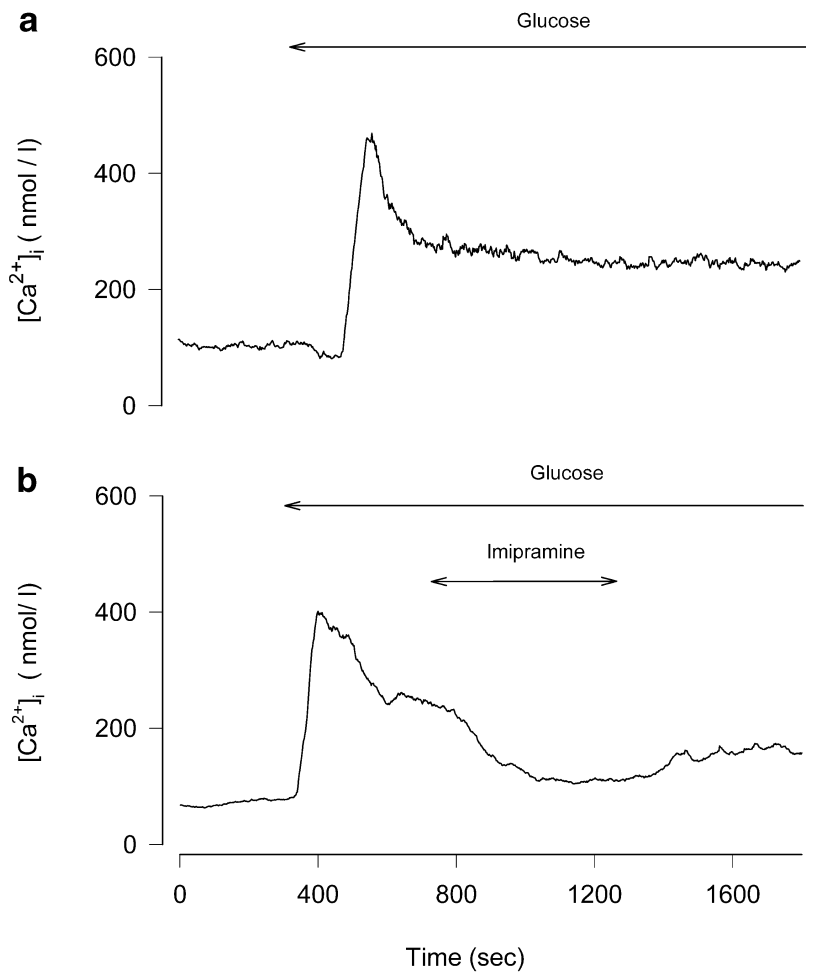

Fig. 5. Effect (a) of $20 \mathrm{mmol} / \mathrm{l}$ glucose on $\left[\mathrm{Ca}^{2+}\right]_{\mathrm{i}}$. b. Effect of $10 \mu \mathrm{mol} / \mathrm{l}$ imipramine on glucose-induced $(20 \mathrm{mmol} / \mathrm{l})$ increase in $\left[\mathrm{Ca}^{2+}\right]_{\mathrm{i}}$. Basal media contained $2.8 \mathrm{mmol} / \mathrm{l}$ glucose and extracellular $\mathrm{Ca}^{2+}$. Each graph is a representative experiment conducted on a single cell

tions between -70 and $0 \mathrm{mV}$ in a single islet cell. The decrease of the peak current was marked and reversible.

The amplitude of the inward currents was used to construct I-V plots. The application of $100 \mu \mathrm{mol} / \mathrm{l}$ imipramine induced (Fig. 4b) a robust decrease of the $\mathrm{Ca}^{2+}$ current without altering its voltage-dependence. At $0 \mathrm{mV}$, the peak current intensity dropped from $-48.4 \pm 4.1 \mathrm{pA}$ in control conditions to $-10.9 \pm 2.4 \mathrm{pA}$ in the presence of $100 \mu \mathrm{mol} / \mathrm{l}$ imipramine $(n=5, p<0.05)$.

Effects of imipramine on the cytosolic free $\mathrm{Ca}^{2+}$ concentration of single rat pancreatic islet cells. A rise in the extracellular glucose concentration from 2.8 to $20.0 \mathrm{mmol} / \mathrm{l}$ provoked a biphasic increase in $\left[\mathrm{Ca}^{2+}\right]_{\mathrm{i}}$, consisting of an initial peak followed by a long-lasting plateau (Fig. 5a). The addition of imipramine $(10 \mu \mathrm{mol} / \mathrm{l})$ during stimulation with $20 \mathrm{mmol} / \mathrm{l}$ glucose reduced the cytosolic free $\mathrm{Ca}^{2+}$ concentration (Fig. 5b). The inhibitory effect of the drug was sustained and slowly reversible.

Figure 6 illustrates the effect of depolarising concentrations of $\mathrm{K}^{+}$on the cytosolic $\mathrm{Ca}^{2+}$ concentration of single islet cells. An increase in the extracellular concentration of $\mathrm{K}^{+}$from 5 to $50 \mathrm{mmol} / \mathrm{l}$ provoked in most cells a monophasic and marked increase in $\left[\mathrm{Ca}^{2+}\right]_{\mathrm{i}}$ (Fig. 6a). In some cells, the $\left[\mathrm{Ca}^{2+}\right]_{i}$ response to 

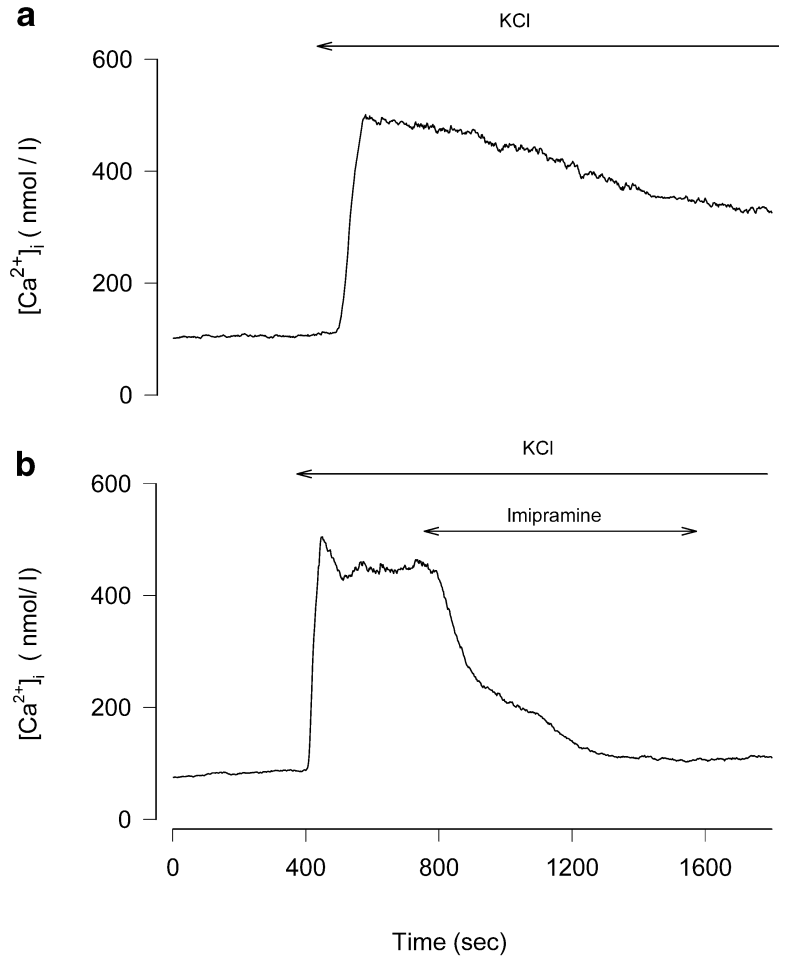

Fig. 6. Effect (a) of $50 \mathrm{mmol} / 1 \mathrm{KCl}$ on $\left[\mathrm{Ca}^{2+}\right]_{\mathrm{i}}$. b. Effect of $10 \mu \mathrm{mol} / \mathrm{l}$ imipramine on $\mathrm{KCl}$-induced $(50 \mathrm{mmol} / \mathrm{l})$ increase in $\left[\mathrm{Ca}^{2+}\right]_{\mathrm{i}}$. Basal media contained $5 \mathrm{mmol} / \mathrm{l} \mathrm{K} \mathrm{K}^{+}, 2.8 \mathrm{mmol} / \mathrm{l}$ glucose and extracellular $\mathrm{Ca}^{2+}$. Each graph is a representative experiment conducted on a single cell

$50 \mathrm{mmol} / \mathrm{l} \mathrm{K}^{+}$was biphasic, an initial peak of short duration being followed by a plateau (Fig. 6b). Whatever the pattern of the $\mathrm{K}^{+}$response, the subsequent addition of imipramine $(10 \mu \mathrm{mol} / \mathrm{l})$ markedly reduced the $\left[\mathrm{Ca}^{2+}\right]_{\mathrm{i}}$ (Fig. $\left.6 \mathrm{~b}\right)$. In the latter condition, the inhibitory effect of imipramine was less readily reversible (Fig. 6b).

In another series of experiments, we examined the effects of $100 \mu \mathrm{mol} / \mathrm{l}$ imipramine on the rises in $\left[\mathrm{Ca}^{2+}\right]_{\mathrm{i}}$ induced by glucose $(20.0 \mathrm{mmol} / \mathrm{l})$ and $\mathrm{K}^{+}$ $(50 \mathrm{mmol} / \mathrm{l})$ (data not shown). In both cases, the addition of $100 \mu \mathrm{mol} / 1$ imipramine again induced marked reductions in $\left[\mathrm{Ca}^{2+}\right]_{i}$. At this concentration, however, the drug acted faster. The removal of $100 \mu \mathrm{mol} / \mathrm{l}$ imipramine from the physiological medium was followed by a delayed increase in $\left[\mathrm{Ca}^{2+}\right]_{\mathrm{i}}$.

\section{Discussion}

We showed that the tricyclic antidepressant imipramine provoked a concentration-dependent inhibition of insulin release from rat pancreatic islets incubated in the presence of insulinotropic (8.3 and $16.7 \mathrm{mmol} / \mathrm{l})$ glucose concentrations.

Dynamic experiments using perifused rat pancreatic islets confirmed the capacity of imipramine to reduce the insulin secretory rate. The latter experimental con- dition further revealed that the secretory response to imipramine was reversible, suggesting that the antidepressant did not damage insulin-secreting cells.

The dose-dependent inhibitory effect of imipramine on the glucose-induced insulin release was reproduced by fluoxetine, a selective serotonin re-uptake inhibitor antidepressant (data not shown). Altogether, these findings confirm those of another study [21] and extend previous observations, indicating that the in vitro reduction of the insulin secretory rate evoked by antidepressants is not restricted to tricyclic antidepressants.

Additional experimental data support the idea that the secretory response to imipramine might be related to modifications in $\mathrm{Ca}^{2+}$ inflow.

Radioisotopic experiments conducted on prelabelled rat pancreatic islets indicated that imipramine elicited a concentration-dependent decrease in ${ }^{45} \mathrm{Ca}$ outflow from islets perifused in the presence of $16.7 \mathrm{mmol} / \mathrm{l}$ glucose and extracellular $\mathrm{Ca}^{2+}$. In islets exposed throughout to calcium and insulinotropic glucose concentrations, the ${ }^{45} \mathrm{Ca} F \mathrm{FOR}$ is known to reflect a sustained stimulation of isotopic exchange between influent ${ }^{40} \mathrm{Ca}$ and effluent ${ }^{45} \mathrm{Ca}$ [22]. Thus, under such experimental conditions, the inhibitory effect of imipramine on ${ }^{45} \mathrm{Ca}$ outflow can be viewed as the result of a reduction of ${ }^{40} \mathrm{Ca}$ entry into the islet cells.

The effects of imipramine on the ${ }^{45} \mathrm{Ca}$ FOR responses to high extracellular $\mathrm{K}^{+}$concentrations also suggest that imipramine dose-dependently reduces $\mathrm{Ca}^{2+}$ inflow. Indeed, in ${ }^{45} \mathrm{Ca}$-loaded pancreatic islets, the increment in ${ }^{45} \mathrm{Ca}$ FOR evoked by high $\mathrm{K}^{+}$again results from the stimulation of a ${ }^{40} \mathrm{Ca} /{ }^{45} \mathrm{Ca}$ exchange process $[12,22]$.

A further argument in support of an inhibitory effect of imipramine on $\mathrm{Ca}^{2+}$ entry can be found in the drug's lack of inhibitory effect on ${ }^{45} \mathrm{Ca}$ outflow from islets exposed to non-insulinotropic glucose concentrations and/or to $\mathrm{Ca}^{2+}$-depleted media.

The electrophysiological experiments conducted on single islet cells confirmed the ability of imipramine to inhibit a tetrodotoxin-insensitive inward current.

The present findings also provide information about the modality of $\mathrm{Ca}^{2+}$ entry affected by imipramine. Indeed, imipramine failed to affect the rate of ${ }^{45} \mathrm{Ca}$ outflow from islets perifused in the presence of $5.6 \mathrm{mmol} / \mathrm{l}$ glucose but markedly inhibited the ${ }^{45} \mathrm{Ca}$ FOR response to $16.7 \mathrm{mmol} / \mathrm{l}$ glucose. Under the latter condition, the depolarising effect of glucose reaches the threshold potential for activation of voltagesensitive $\mathrm{Ca}^{2+}$ channels.

The inhibitory effects of imipramine on the $\mathrm{KCl}$ induced changes in ${ }^{45} \mathrm{Ca}$ outflow further suggest that the drug interfered with a voltage-sensitive modality of $\mathrm{Ca}^{2+}$ entry.

Moreover, patch-clamp experiments revealed that imipramine decreased the amplitude of a voltage-sensitive inward current with gating properties similar to the L-type $\mathrm{Ca}^{2+}$ channels equipping rat beta cells [20]. 
Incidentally, the effects of imipramine on the cationic responses to glucose and $\mathrm{KCl}$ depolarisation are reminiscent of those evoked by $\mathrm{Cd}^{2+}$ or verapamil, two calcium channel blockers known to interact with the L-type $\mathrm{Ca}^{2+}$ channels [12, 22, 23, 24].

Thus, all these observations support the view that imipramine reduced $\mathrm{Ca}^{2+}$ entry by inhibiting the L-type voltage-sensitive $\mathrm{Ca}^{2+}$ channels. Previous studies on cardiac and neuronal cells also revealed that imipramine has an inhibitory effect on an inward $\mathrm{Ca}^{2+}$ current $[25,26]$.

A decrease in $\mathrm{Ca}^{2+}$ entry as mediated by imipramine should be followed by a reduction in the cytosolic $\mathrm{Ca}^{2+}$ concentration. In agreement with this, calcium fluorimetry experiments conducted on single islet cells confirmed the ability of imipramine to counteract the increase in $\left[\mathrm{Ca}^{2+}\right]_{\mathrm{i}}$ elicited either by insulinotropic concentrations of glucose or by high $\mathrm{K}^{+}$concentrations.

This effect on $\left[\mathrm{Ca}^{2+}\right]_{\mathrm{i}}$, a key element in the stimulus-secretion coupling process, probably triggers the decrease in insulin output. Such a view is also substantiated in the observation that the secretory responses to imipramine mirrored the ${ }^{45} \mathrm{Ca}$ FOR data.

In addition to inhibitory effects on plasma membrane $\mathrm{Ca}^{2+}$ channels, $100 \mu \mathrm{mol} / 1$ imipramine also elicited a small, sustained and slowly reversible increase in ${ }^{45} \mathrm{Ca}$ FOR from islets exposed to $16.7 \mathrm{mmol} / \mathrm{l}$ glucose and $\mathrm{Ca}^{2+}$-free media. This suggests that a high concentration of imipramine might also provoke intracellular calcium redistribution with subsequent changes in ${ }^{45} \mathrm{Ca}$ outflow $[11,27,28]$.

In conclusion, our data indicate that the tricyclic antidepressant imipramine reduces the glucose-sensitive insulin output from rat pancreatic beta cells. This effect results from the inhibition of voltage-sensitive $\mathrm{Ca}^{2+}$ channels with subsequent reduction in $\mathrm{Ca}^{2+}$ entry.

Although serum concentrations of imipramine at typical clinical doses are lower $(\sim 0.5-1.0 \mu \mathrm{mol} / \mathrm{l})$, it should be kept in mind that the plasma concentrations of this tricyclic antidepressant can reach higher levels, e.g. through overdosage, deficient elimination and drug interactions [29]. Moreover, numerous data indicate that imipramine, like other antidepressants, is extensively bound to tissue protein and accumulates in the cells $[30,31,32]$. From a clinical viewpoint, therefore, and taking into account the species differences, it is possible that the side-effect profile of imipramine is related, at least in part, to its ability to act as a $\mathrm{Ca}^{2+}$ entry blocker.

Acknowledgements. The authors are grateful to A. van Praet and F. Leleux for technical assistance and to J. Brunko for secretarial help. P. Lebrun is Research Director of the National Fund for Scientific Research (Belgium).

\section{References}

1. Anderson RJ, Freedland KE, Clouse RE, Lustman PJ (2001) The prevalence of comorbid depression in adults with diabetes. Diabetes Care 24:1069-1078

2. Goodnick PJ, Henry HJ, Buki MVM (1995) Treatment of depression in patients with diabetes mellitus. J Clin Psychiatry 56:128-136

3. Gomez R, Huber J, Tombini G, Baros HMT (2001) Acute effect of different antidepressants on glycemia in diabetic and non-diabetic rats. Braz J Med Biol Res 34:57-64

4. Goodnick PJ (2001) Use of antidepressants in treatment of comorbid diabetes mellitus and depression as well as in diabetic neuropathy. Ann Clin Psychiatry 13:31-41

5. Frazer A (1997) Pharmacology of antidepressants. J Clin Psychopharmacol 17:2S-18S

6. Ventulani J, Nalepa I (2000) Antidepressants: past, present and future. Eur J Pharmacol 405:351-363

7. Kaplan SM, Mass JW, Pixley JM, Ross WD (1960) Use of imipramine in diabetics. J Am Med Assoc 174:119-125

8. Shrivastava RK, Edwards D (1983) Hypoglycemia associated with imipramine. Biol Psychiatry 18:1509-1510

9. Erenmemisoglu A, Ozdogan UK, Saraymen T, Tutus A (1999) Effect of some antidepressants on glycaemia and insulin levels of normoglycaemic and alloxan-induced hyperglycaemic mice. J Pharm Pharmacol 51:741-743

10. Yamada J, Sugimoto Y, Inoue K (1999) Selective serotonin inhibitors fluoxetine and fluvoxamine induce hyperglycemia by different mechanisms. Eur J Pharmacol 382:211215

11. Antoine M-H, Ouedraogo R, Sergooris J, Hermann M, Herchuelz A, Lebrun P (1996) Hydroxylamine, a nitric oxide donor, inhibits insulin release and activates $\mathrm{K}^{+}$ATP channels. Eur J Pharmacol 313:229-235

12. Lebrun P, Arkhammar P, Antoine M-H, Nguyen Q-A, Bondo-Hansen J, Pirotte B (2000) A potent diazoxide analogue activating ATP-sensitive $\mathrm{K}^{+}$channels and inhibiting insulin release. Diabetologia 43:723-732

13. Leclercq-Meyer V, Marchand J, Woussen-Colle MC, Giroix MH, Malaisse WJ (1985) Multiple effects of leucine on glucagon, insulin and somatostatin secretion from the perfused rat pancreas. Endocrinology 116:1168-1174

14. Lebrun P, Malaisse WJ, Herchuelz A (1985) Do hypoglycemic sulfonylureas inhibit $\mathrm{Na}^{+}, \mathrm{K}^{+}$-ATPase activity in pancreatic islets? Am J Physiol 248:E491-E499

15. Lebrun P, Antoine M-H, Ouedraogo R et al. (1996) Activation of ATP-dependent $\mathrm{K}^{+}$channels and inhibition of insulin release: effect of BPDZ 62. J Pharmacol Exp Ther 277:156-162

16. Pipeleers D (1987) The Biosociology of pancreatic B cells. Diabetologia 30:277-291

17. Horn R, Marty A (1988) Muscarinic activation of ionic currents measured by a new whole-cell recording method. J Gen Physiol 92:145-159

18. Hamill OP, Marty A, Neher E, Sakmann B, Sigworth FJ (1981) Improved patch-clamp techniques for high-resolution current recording from cells and cell-free membrane patches. Pflugers Archiv 391:85-100

19. Rorsman P, Ämmälä C, Berggren P-O, Bokvist K, Larsson O (1992) Cytoplasmic calcium transients due to single action potentials and voltage-clamp depolarizations in mouse pancreatic B-cells. EMBO J 11:2877-2884

20. Hiriart M, Matteson DR (1988) Na channels and two types of $\mathrm{Ca}$ channels in rat pancreatic $\mathrm{B}$ cells identified with the reverse hemolytic plaque assay. J Gen Physiol 91:617639 
21. El-Dakhakhny M, Abdel El-Latif HA, Ammon HPT (1996) Different effects of the antidepressant drugs imipramine, maprotiline and bupropion on insulin secretion from mouse pancreatic islets. Arzneimittelforschung 46:667-669

22. Lebrun P, Malaisse WJ, Herchuelz A (1982) Evidence for two distinct modalities of $\mathrm{Ca}^{2+}$ influx into the pancreatic B-cell. Am J Physiol 242:E59-E66

23. Godfraind T, Miller R, Wibo M (1986) Calcium antagonism and calcium entry blockade. Pharmacol Rev 38:321416

24. Plasman PO, Hermann M, Herchuelz A, Lebrun P (1990) Sensitivity to $\mathrm{Cd}^{2+}$ but resistance to $\mathrm{Ni}^{2+}$ of $\mathrm{Ca}^{2+}$ inflow into rat pancreatic islets. Am J Physiol 258:E529-E533

25. Isenberg G, Tamargo J (1985) Effect of imipramine on calcium and potassium currents in isolated bovine ventricular myocytes. Eur J Pharmacol 108:121-131

26. Choi JJ, Huang G-J, Shafik E, Wu W-H, Mc Ardle JJ (1992) Imipramine's selective suppression of an L-type calcium channel in neurons of murine dorsal root ganglia involves G proteins. J Pharmacol Exp Ther 263:49-53
27. Antoine M-H, Hermann M, Herchuelz A, Lebrun P (1991) Ionic and secretory response of pancreatic islet cells to minoxidil sulfate. J Pharmacol Exp Ther 258:286-291

28. Lebrun P, Malaisse WJ, Herchuelz A (1982) Nutrientinduced intracellular calcium movement in rat pancreatic B-cell. Am J Physiol 243:E196-E205

29. Baldessarini RJ (2001) Drugs and the treatment of psychiatric disorders. Depression and anxiety disorders. In: Hardman JG, Limbird LE (eds) Goodman \& Gilman's The pharmacological basis of therapeutics, 10th edn. McGraw-Hill, New York, pp 447-483

30. Novelli A, Lysko PG, Henneberry RC (1987) Uptake of imipramine in neurons cultured from rat cerebellum. Brain Res 411:291-297

31. Honegger UH, Roscher AA, Wiesmann UN (1983) Evidence for lysosomotropic action of desipramine in cultured human fibroblasts. J Pharmacol Exp Ther 225:436-441

32. Karson CN, Newton JE, Livingston R et al. (1993) Human brain fluoxetine concentrations. J Neuropsychiatry Clin Neurosci 5:322-329 